\title{
Insertion of nursing professionals in the management of materials in a teaching hospital of Paraná
}

\author{
Inserção dos profissionais de enfermagem no gerenciamento \\ de materiais em hospital universitário do Paraná \\ Inserción de profesionales de enfermería en gestión de \\ materiales en hospital universitario en Paraná
}

\section{Raísa Gabrielle dos Santos Andrade \\ Priscila Conde Bogo ${ }^{b}$ \\ Nelsi Salete Tonini ${ }^{\mathrm{a}}$ \\ Fabiana Gonçalves de Oliveira Azevedo Matos ${ }^{\mathrm{a}}$ \\ Debora Cristina Ignácio Alves ${ }^{a}$}

\section{How to cite this article:} Andrade RGS, Bogo PC, Tonini NS, Matos FGOA, Alves DCI. Insertion of nursing professionals in the management of materials in a teaching hospital of Paraná. Rev Gaúcha Enferm. 2021;42:e20200069. doi: https://doi.org/10.1590/19831447.2021.20200069
Universidade do Oeste do Paraná (UNIOESTE). Cascavel, Paraná, Brasil.

Hospital Universitário do Oeste do Paraná (HUOP). Cascavel, Paraná, Brasil.

\section{ABSTRACT}

Objectives: To analyze the perception of nursing professionals about their insertion in the material management process in hospital units.

Methods: Exploratory study with a qualitative approach carried out in a university hospital in Paraná. Data collection was carried out between October and December 2019, through semi-structured interviews recorded in audio. The data were transcribed and submitted to thematic content analysis.

Results: 35 nursing professionals participated in the study. From the speeches, four categories emerged: Participation in the process of planning and provision of materials; Sizing of resources in the institution; Participation in the quality control of materials; and Difficulties confronted in the material management process.

Conclusion: The results indicate that nursing professionals have a low participation in the material management process and infer that they actively participate only in the quality control process through evaluations and notifications.

Keywords: Nursing. Hospital administration. Materials management, hospital. Material resources in health.

\section{RESUMO}

Objetivos: Analisar a percepção dos profissionais de enfermagem sobre a sua inserção no processo de gerenciamento de materiais em unidades hospitalares.

Métodos: Estudo exploratório de abordagem qualitativa realizado em um hospital universitário no Paraná. A coleta de dados foi realizada entre outubro a dezembro de 2019, por meio de entrevista semiestruturada e gravada em áudio. Os dados foram transcritos e submetidos à análise de conteúdo temática.

Resultados: Participaram do estudo 35 profissionais de enfermagem. Dos discursos, emergiram quatro categorias: Participação no processo de planejamento e provimento dos materiais; Dimensionamento de recursos materiais; Participação no controle de qualidade dos materiais; e, Dificuldades enfrentadas no processo de gerenciamento de materiais.

Conclusão: Os resultados indicam que os profissionais de enfermagem possuem uma baixa participação no processo de gerenciamento de materiais, e inferem que participam ativamente somente do processo de controle de qualidade por meio das avaliações e notificações.

Palavras-chave: Enfermagem. Administração hospitalar. Administração de materiais no hospital. Recursos materiais em saúde.

\section{RESUMEN}

Objetivos: Analizar la percepción de los profesionales de enfermería acerca de su inserción en el proceso de gestión de materiales en unidades hospitalarias.

Métodos: Estudio exploratorio con enfoque cualitativo realizado en un hospital universitario en Paraná. Se realizó a la recogida de los datos entre octubre y diciembre de 2019, a través de entrevistas semiestructuradas y grabadas en audio. Se transcribió a los datos y se los sometió a un análisis de contenido temático.

Resultados: Participaron en el estudio 35 profesionales de enfermería. Surgieron cuatro categorías de los discursos: Participación en la planificación y provisión de materiales; Dimensionamiento de recursos materiales; Participación en el control de calidad de materiales; $y$, Dificultades enfrentadas en el proceso de gestión de materiales.

Conclusión: Los resultados indican que los profesionales de enfermería tienen una baja participación en el proceso de gestión de materiales, e infieren que solo participan activamente en el proceso de control de calidad a través de evaluaciones y notificaciones. Palabras clave: Enfermería. Administración hospitalaria. Administración de materiales de hospital. Recursos materiales en salud. 


\section{口INTRODUCTION}

Hospitals are complex structures that promote the recovery of the health of the patients using physical, human, material, and financial resources. As a result, these resources need to be allocated through actions targeted at planning, distribution, and control(1).

Technological advances in health have been increasing assistance complexity and demand a higher level of attention from the professionals involved in the management of these resources, both in private and public sectors, since these are essential items that directly influence in the quality of the care offered $^{(2-3)}$.

Simultaneously, Health Assistance Facilities (EAS) face challenges due to increased costs, budget cuts, and diminished government investment ${ }^{(1)}$. Therefore, the sources that pay and fund the health services, such as the Single Health System (SUS), pressure institutions to adequate their processes of work and management with the objective of optimizing the resources invested and reiterate the commitment of using public money well, while also improving their offer of services to the population ${ }^{(4)}$.

Therefore, there has been a global trend for EASs to search and rethink practices of resource management and quality control, as well as the cost of health care ${ }^{(1)}$.

The report presented by the World Health Organization (WHO) in 2010, about the financing of health systems, addresses efficiency and the elimination of waste. It presented data about the importance of guaranteeing an efficient use of resources in all countries. The Ministry of Health (MS), on the other hand, published in 2013 a document that describes the actions to improve SUS, thus guaranteeing a quality attention for its users. Among them, is the "improvement of management and of the combat against the waste of resources"(3).

The Management of Materials (MM) in the hospital can be a unit to give support to the reduction of costs and prejudice. The functioning of assistance units depends on the involvement of professionals connected to the areas of effective consumption, to ensure an adequate use of materials with as little waste as possible ${ }^{(5)}$.

Therefore, one of the strategies adopted to improve the MM processes is approximating the sector that uses the material to the administrative instances of purchase, through technical counseling and commissions made with the participation of different professional categories ${ }^{(4)}$.

Considering that the nursing team is the largest among the groups that take part in health care, being nurses, therefore, the users that demand the most from the EAS, the role of nurses stand out in the MM. After all, they are responsible for managing attention units, coordinating all assistance activities with the technical team, and for the forecast, provision, control, and assessment of the resources used for the health team ${ }^{(2-4)}$.

Therefore, it is important to highlight that the nurse has an active role in the MM process, which is the evaluation of the material resources used in institutions. That is made clear by their knowledge in this process and by their preoccupation with the qualification of the products used in nursing assistance, in addition to managing the costs for the institution(6).

The considerations above are related to the justification to carry out studies that present strategies to improve the process of management of materials in the units that use them, through the perception of the nursing team with regard to their participation in this process, since they have the technical and practical knowledge about Products For Health $(\mathrm{PFH})$, and their impact in the control of these materials in the assistance units. As a result, the guiding question of this study was: "What is the perception of the nursing team with regard to their insertion in the MMs of the units of assistance of a teaching hospital in a hinterland city of Paraná?".

As a result, considering the presuppositions mentioned above, this study is believed to be able to contribute to improve the actions of nurses in the MM process. To do so, the objective of this study is to analyze the perception of nursing professionals about their insertion in the process of managing materials in hospital units.

\section{METHODS}

This is an exploratory study, following a qualitative approach. The study was carried out in a medium-complexity public university hospital, integrated to the SUS, in the hinterland of Paraná. The setting of the research included the Emergency Room (ER), the Adult Intensive Care Unit (ICU), and the Medical and Surgical Clinic Unit. These units were selected because their profile indicate the highest consumption of materials.

14 nurses were interviewed, in addition to 18 nursing technicians and 3 nursing auxiliaries. The inclusion of nursing technicians and auxiliaries in this study is due to Law No. 7498/86, that regulates the Professional Exercise of Nursing, which attributes to them the important role of participating in the management of materials in the assistance units, especially aiding nurses to plan the nursing assistance ${ }^{(7)}$.

The number of participants was defined through data saturation. The saturation sample is used to establish sample sizes. In this technique, the number of participants is operationally defined by the suspension of the inclusion of new participants when the data obtained starts to present 
redundancy or repetition, according to the researcher. It can also be suspended after the interview has been carried out with all representatives of a certain group or category, and persisting in data collection becomes irrelevant ${ }^{(8)}$.

The inclusion criteria to participate in the study were: professionals with some type of employment bond, who were working for more than one year in the institution at time of data collection, and who work in the units of the Emergency Room (ER), Adult Intensive Care Unit (ICU), or in the Medical and Surgical Clinical Unit.

The nursing professionals accepted formally to participate beforehand, acceptance which was represented by the signing of the Free and Informed Consent Form (FICF). Data collection was carried out from October to December 2019.

Semi-structured interviews were used as the script for data collection. They were made up of closed questions that allowed an identification of the profile of the interviewees. Open questions were related to the theme of the research, asking for an answer to five questions that were lined up with the context of the objective of the research: 1) What are the materials involved in your work process during patient assistance? 2) How do you participate in the process of material management in your unit? 3) Considering the amount and quality of materials in your unit, how do you participate in this process? 4) What do you find easy and difficult in the process of managing the materials in your unit? 5) In your opinion, what would be the ideal process for the functioning of material management in the institution?

The semi-structured interviews were carried out in the institution itself, in a private location, during the working hours of the professionals. Therefore, it stands out that they were carried out individually, according to the availability of each participant, so that the interference with the assistance process could be as small as possible.

The interviews were recorded in an audio device. There was not a specified length for the interviews, and, after finished, they were transcribed in full. They were identified using the letters "E" for Nurses, "NT" for nursing technicians", and "AUX" for Nursing Auxiliaries, followed by the number of the interview, always respecting the anonymity of the interviewees.

To analyze the data, the Content Analysis method by Bardin was used, which is"... a body of techniques to analyze communication processes, which aims at obtaining, through systematic and objective procedures, a description of the content of the messages, indexes (whether quantitative or not) which allow for the inference of meanings regarding the conditions of production/reception (inferred variables) of these messages"(9).
The organization of content analysis is carried out in three stages, including the pre-analysis, in which all the material collected from the interviews was skimmed and then read exhaustively. Later, data was analyzed separating the important extracts and fragments from the material and distributing them in topics and information units. All information units were then brought together, creating the meaning cores. After this approximation was carried out and the analytical work involving the meaning cores, the analytical categories that guided the study emerged. The same is true for the treatment of the results, the inferences and interpretations, from which an interpretation synthesis was carried out The results found were treated and submitted to simple or complex interventions which made it possible to highlight the data found by the study ${ }^{(9)}$.

All ethical precepts established by Resolution No. 466/2012 from the National Council of Health were respected, and this study was approved by the Research Ethics Committee from the Universidade Estadual do Oeste do Paraná (UNIOESTE), CAAE No. 50066815.8.0000.0107, under legal opinion No. 3.062.301.

\section{RESULTS AND DISCUSSION}

The study counted on the participation of 35 professionals from the nursing team, who worked in the units selected to carry out the study; 14 of them were assistance nurses; 18 were nursing technicians; and 3 were nursing auxiliaries. Among them, 30 (85\%) were female, and the most common age group was from 36 to 40 . With regard to the time since finishing their graduation, most nurses had finished it from 11 to 15 years; nursing technicians and auxiliaries had been graduated from 16 to 20 years.

This finding corroborates those of a study on the sociodemographic profile of the nursing team, according which it is formed mostly by women from 26 to 50 years old, who are in a state of professional maturity and almost always have a graduation and a specialization ${ }^{(10)}$.

Almost all the 13 (93\%) nurses interviewed, and a part of the nursing technicians, had one or more training or specialization courses.

It stands out that, although nursing technicians have medium-level roles in the institution, 12 (57\%) were graduated nurses, and, as a result, stated to be post-graduated. This situation indicates an objective of changing one's field of work, or, sometimes, an attempt to ascend in the nursing career.

From the professionals interviewed, 25 (71\%) reported not having received any training about the process of managing 
materials from the institution when they were admitted, or even afterwards.

Permanent education is seen as an important and decisive element for the quality of nursing assistance. It is based on technical and scientific knowledge and focused on training and courses, to adequate the team to the work in the respective unit. The training, when carried out based on necessity, is essential for the sustainable and stable development of a profession and in the organizational restructuring, so that results can reflect in the type of hospitalization, the economy of medical resources, and in the quality of life of patients ${ }^{(11)}$.

Data related to the object of study was categorized, according to the core meanings, in four groups: Participation in the process of planning and provision of materials; Sizing of resources in the institution; Participation in the quality control of the materials; Difficulties confronted in the MM process. These will be discussed below.

\section{Participation in the process of planning and provision of materials}

The scope of the MM includes from the acquisition of essential materials to produce new health services to making these materials available. Its objective, in fact, is making these resources available in an adequate quantity and quality, in the adequate time and with a lower cost ${ }^{(12)}$.

Nurses have an important role with regard to determining the materials needed for assistance, both with regard to quantity and to quality, since these professionals are responsible for managing attention units and for coordinating the activity of assistance as a whole ${ }^{(2)}$.

When asked how do they fit in the MM process in their units, the nursing professionals showed, through their discourses, to have a limited participation in the management of material resources in the attention units, as can be seen below:

[...] today, very often, we have clerks, but the nurse, often, also does that quote unquote "planning" of what should be spent too. (N4).

[...] when I started it was already partly instituted, the person who basically makes the materials available and stuff, who restocks, everything, is the intern [...] When he isn't here weend up seeing how much we miss it [...]. (N8)

[...] the clerk is the one who does that, and when he isn't here, it's the weekend, and some material is missing, since he leaves all the requests in the pharmacy, we only have to go there Saturday and Sunday to fetch the packs he requested. (NT20)
The importance of the involvement of the nurse in the process of managing material resources aims to guarantee the efficiency of nursing assistance, so it is not interrupted by the lack of materials, be it in their quantity or in their quality ${ }^{(2,13)}$.

Therefore, the low participation of these professionals in the planning and provision of the materials used in the assistance units can have a negative effect on the care offered, exposing the patient to the inherent risks associated to it.

It is important for the teams to get closer to the process of material management in the health services, in order to improve the quality of the assistance provided and aid in the control of institutional expenses.

However, the determination of direct and indirect care to the patient is not always known by the professionals in hospital work. Also, the limits between care, management of care, and management of institution resources are not noticeable ${ }^{(1)}$.

However, it can be noted that this role is attributed to the administrative auxiliary (intern), that is, the role of forecasting and providing the materials for the units of attention. This can be noted in the discourses of part of the health team, which can show how far the team is from this process, which is considered to be one of their attributions. However, the role of these professionals should be to aid the nursing team in the search and storage of these materials, referring documents and organizing the unit, in addition to other activities that are compatible with their role.

In addition to being the main actors of the nursing team, nurses must, within the managerial skills that are expected from them, manage physical, material, human, and information resources, solve problems, size resources, plan their application, develop strategies, and carry out situational diagnostics, which demands knowledge and abilities found in the performance of their functions ${ }^{(14)}$.

With regard to nursing technicians and auxiliaries, considering the attributions established by Law No. 7498/86, they must, respectively, participate in the programming of nursing assistance and zeal for the order of the materials and equipment on which the unit depends ${ }^{(7)}$.

For a quality assistance to be offered, managerial and assistance actions must be integrated, and the nurse must have up-to-date information with regard to the fundamental aspects of the unit, such as the choice of the medical-hospital materials ${ }^{(15)}$.

Currently, there is a demand for patients to receive a quality assistance with the maximum efficiency in the use of the resources available. However, it stands out that, when professionals are not involved in the management of the 
supplies, this can lead to the uncontrolled use of resources, their waste, and increase the direct and indirect costs of a quality assistance.

\section{Sizing of resources in the institution}

It is important to highlight that, when questioned about what would be the ideal process for MM in the institution, the professionals interviewed were found not to understand the question, since one of the relevant issues observed in the discourses was the sizing of resources.

The material forecast is defined according to the amount of material required by the units'storage rooms, and the use profile of each of them. Through this data, a quota is established to estimate expenses for a certain period. It is considered to be a component of stock control which aids in managerial actions and determines the amount of expenses, also considering safety stocks ${ }^{(2)}$.

In this regard, interviewees reported the importance of maintaining a better control over materials, to avoid the lack of materials in the assistance and in the stock of the units:

[...] actually it would be necessary to know how much is spent in each sector in a certain shift, so that we know how much to ask them not to have to work with those largestocks. Sometimes, a certain wing has material left over while another is lacking. (N7).

[...] in this case, it's control. [...] to see the amount being used daily and replenish it according to the demand, instead of stocking the materials. (NT6)

In the process of managing material resources, the fundamental role of nurses stand out, which is that of knowing and monitoring the use of these resources in the unit under their responsibility, since the stock forecast must attend to the demands. However, managers must solve problems such as the variability between the actual demand and the forecast demand for supplies in the institutions, since this variation can be responsible for oversized or undersized stock levels ${ }^{(16-17)}$.

[...] We do not decide the amount of materials that is put there, and we use what we have, if there is no more we end up requesting for more. (NT4).

[...] you know, I never stopped and thought, if we have more or less than the amount measured? (NT12)

As a result, the sizing of resources is directly linked to the lack of integration of managerial and assistance actions, and to the distancing from the teams to the MM process.
The little participation of professionals in the monitoring of the use of materials in their unit shows a weakness in the process of management of material resources. This is true for both the entire institution and for the units studied, the management depends on an informed, aware, and active team, that participates in the administration of these resources to prevent interruptions in the attention offered.

One of the difficulties in the management of materials is based on the lack of planning of nurses for the provision of strategies related to the care offered, including their failure to use simple methods to control the stock of materials, such as, for instance, calculating a safety stock ${ }^{(18)}$.

The little participation of nurses in the process contributes for incorrect forecasts and mistaken provisions of materials in the attention units, which may lead to the oversizing or undersizing of the stock of materials, in addition to bringing financial losses to the institution, due to the waste of resources or to the lack of them in the assistance.

Therefore, it is clear that the nursing team must be involved in the MM, to assume an active posture with regard to this aspect. Also, they must be co-responsible for stocking, controlling quantity and quality, and monitoring the efficiency of the products after they were acquired ${ }^{(12)}$.

\section{Participation in the quality control of the material}

In the MM process, the quality of the products is an important element. The need to control the quality of the supplies in the institution is undeniable, both with regard to products being used and to the process of acquiring them ${ }^{(2,15)}$.

The evaluation of materials should be done together with the multidisciplinary team who uses them, since the commitment of the professionals with this activity is a good way to search for improvements in the quality of the service, involving them and making them co-responsible ${ }^{(4)}$.

When asked about the quality control of the materials used in the unit where they act, it became clear that the nursing professionals are inserted in this process as evaluators of the products acquired by the institutions through biddings, trading floor, and through the filling in of the Form of Incidents and Adverse Events, instituted by the Center of Patient Safety and Quality Management of the institution. All of this can be seen in the discourses below:

[...] with regards to quality, the hospital has bidding processes and more often than not they trade brands and suppliers and then, when there is any defect, something, we notify, attach the material and ask them not 
to buy anymore and for, in some cases, the entire lot to be removed. (N8)

[...] we notify. Actually, that's it, this is how we participate. (N10)

[...] with regard to quality I think that every time a material that is bad comes, we fill in the notification sheet to reprove or not, to approve the material, but this is our participation. I don't see what a technician could do regarding this. (NT8)

Through the statements, it was possible to find that the nursing professionals participated in the surveillance of the quality of the products used in the assistance to avoid possible damages to the working process and to the patient. The input of these professionals about the quality of the products used in the institution reiterates the importance of their involvement in the process of managing materials in the hospital studied, in addition to making them co-responsible for the surveillance of these products.

As a result, it becomes clear that the attributes of these products influence in the quality of the assistance offered and have profound repercussions in the safety of nursing workers during the provision care ${ }^{(15)}$.

Therefore, the process of notification of the technical complaint, and that of material for hospital use, is seen as a tool that aids the MM, in addition to producing information with subsidies for decision making, which makes the investigation of the facts reported possible. This includes making notifications about the product through the system of Sanitary Surveillance Notification (NOTIVISA), in addition to offering technical opinions about the product during the bidding process ${ }^{(6)}$.

When professionals are part of the evaluation process of the products and of their quality control, it means the institution is becoming closer to them in the MM process, making it easier to evaluate products in later purchasing processes of the institution and making it possible to elaborate a list of products that have already been evaluated and approved by the professionals. This can lead to an increase in the quality of the care provided.

Although the institution researched has a service of Health Products Standardization, coordinated by a nurse who is present in the elaboration of biddings for the purchasing of medical-hospital supplies, it is important to highlight that the nursing team that participated in the study states that they do not feel inserted in any other stage of the MM process in the institution, when they should be involved in all stages the forecast, the provision, the control, and the evaluation.

\section{Difficulties confronted in the MM process}

The purchasing process in public institutions is carried out through biddings. It seeks to attend a specific demand through administrative acts or actions, supported by Law No. 8666/93, aiming to seek the proposal that offers the most advantage for public administration, as long as certain principles are respected ${ }^{(12)}$.

The management of material resources in the private sector is subject to the rules of the market, and the sector must manage it with competitive prices. The public sector does not follow the same rules, since, due to its restrict budget, it needs a greater control over the use and the cost of the supplies (2).

What was found in the statements of the interviewees was the lack of planning by the institution, which could be linked to the bidding process, the bureaucracy involved, and influences patient assistance.

[...] the problem is that it seems that there is no adequate planning. I'll give you an example, sterile gauzes to dress wounds because there is not enough material for it, sometimes, we have to use another material that is more expensive because we lack the other one [...] (N5)

Therefore, attention must be given to the $\mathrm{MM}$ with regard to its logistics and to the management of supplies that are essential for patient care to function properly. However, ruptures in the hospital supply chain can be found that are related to many risk factors and vulnerabilities, which have been generating a lack of supplies or even interruptions in the assistance ${ }^{(17)}$.

\section{[...] there's no material, we don't have it because it depends on biddings or because the company delayed the delivery, or even because the hospital didn't buy it. (N2) \\ [...] It's difficult when there's no material, you have to use something that is not what you should use, but you have to use it because it's all there is. (NT2)}

Therefore, the dependence on the bidding process to acquire materials can generate another type of waste in the institutions, generated by the use of unnecessary supplies which are, often, more expensive. The purchasing process in public institutions is generally slower, and, in many situations, leads to the lack of basic materials, without which the professionals cannot work and/or whose lack prejudice the assistance provided, in addition to forcing professionals to 
use more expensive materials, which can lead to losses in the costs of the institution ${ }^{(19)}$.

Due to the diminution of resources for public institutions and to the increasing complexity of health care, public hospitals have not been able to adequately attend to the needs of supplies and equipment, which has been leading working conditions to become increasingly precarious. Therefore, the evident lack, insufficiency, or inadequacy of material resources leads workers to adapt and improvise materials and equipment ${ }^{(20)}$.

Therefore, the EAS must invest in improvements for the purchasing processes of supplies and materials, with a better planning for biddings, to avoid the risk factors that can take place during the process, in addition to problems that may interfere in the assistance to the patient.

Therefore, the distancing of the nursing team in the MM process may be contributing to the insufficiency of resources and to the waste of the products used in assistance. Therefore, the participation of professionals in the processes of MM and EAS is necessary to adequate costs and material resources for assistance.

\section{FINAL CONSIDERATIONS}

The results suggest that nursing professionals have little participation in the process of material management and are recognize themselves to be more present in the process of quality control, and in the sending of notifications about the affected sector.

Therefore, the lack of recognition of the professionals about their importance in the management of material resources in health care units may be related to the low involvement of nurses from the attention units in the other stages of the management process, to the lack of dissociation of the roles with regard to the management of care, and to the management of material resources. This can become a great impairment to health institutions when it comes to controlling direct and indirect costs involved in the care provided.

Therefore, institutions need to rethink forms of management aiming to enable the participation, knowledge, and involvement of professionals in the work developed. This would improve the purchasing process, readapt and minimize costs in the management of material resources, and collaborate towards the reduction of costs and the improvement of the quality of the assistance offered to the patients.

However, health institutions must implement education strategies and expand the spaces where the theme can be discussed between the professionals involved in the management of the materials - especially nurses, considering their important role in the improvement of the health care being provided, and in the assurance of the quality of the material resources used. This would be a way to bring them closer to the theme and to show that this is one of their responsibilities.

A limitation of this study is the fact that its setting was made up of only three health care units in the institution studied. That was done because, once we considered that these units consumed higher amounts of materials, it was thought that the professionals in these sectors would be more active in the process of material management, due to the profile and to the complexity of the patients attended in these units.

The study concluded here aims to collaborate to an indepth analysis of the theme "management of materials". It can also contribute for the improvement in the actions of the nurse in the process of material resources management in the assistance units. It can also aid in an assessment of the way this theme is addressed in the education of these professionals, by pointing out their difficulties in this context. Additionally, the data resulting from this study can contribute to improve this process in the Health Assistance Facilities and in the attention units. This data can also encourage new studies that can further develop the understanding and participation of nursing professionals in the management of materials in other settings, considering the "modus operandi" of this process.

\section{REFERENCES}

1. Ventura PFEV, Freire EMR, Alves M. Participação do enfermeiro na gestão de recursos hospitalares. Rev Eletrôn Gestão Saúde. 2016 [citado 2020 jan 15];7(1):126-47. Disponível em: https://periodicos.unb.br/index.php/rgs/ article/view/3398

2. Castilho V, Mira VL, Lima AFC. Gerenciamento de recursos materiais. In: Kurcgant P. coordenadora. Gerenciamento em enfermagem. Rio de Janeiro: Guanabara Koogan; 2016. p. 145-57.

3. Reichert MCF, Lozovoi TG, D'innocenzo M. The waste of assistance material perceived by nursing students. Rev Eletr Enf. 2017;19:a27. doi: https://doi. org/10.5216/ree.v19.42243

4. Bogo PC, Bernardino E, Castilho V, Cruz EDA. The nurse in the management of materials in teaching hospital. Rev Esc Enferm USP. 2015;49(4):632-9. doi: https://doi.org/10.1590/S0080-623420150000400014

5. Almeida LM, Silva HTH. Equipamento médico-hospitalar: uma gestão na área da saúde. Interdisc J Health Educ. 2016;1(1)32-9. doi: https://doi.org/10.4322/ ijhe2016007

6. Gil R, Chaves $L$, Laus A. Management of material resources with a focus on technical complaints. Rev Eletr Enferm. 2015;17(1):100-7. doi: https://doi. org/10.5216/ree.v17i1.27544 
7. Presidência da República (BR). Lei no 7498, 25 de junho de 1986. Dispõe sobre a regulamentação do exercício da enfermagem e dá outras providências. Legislação do exercício de enfermagem. Brasília, DF; 1986 [cited 2020 Jan 15]. Available from: http://www.planalto.gov.br/ccivil_03/ LEIS/L7498.htm

8. Falqueto J, Farias J. Saturação teórica em pesquisas qualitativas: relato de uma experiência de aplicação em estudos na área de administração. Investig Qualitat Ciênc Soc. 2016 [cited 2020 Jan 15];3:560-9. Available from: https:// proceedings.ciaiq.org/index.php/ciaiq2016/article/view/1001/977

9. Bardin L. A análise de conteúdo. Lisboa: Edições 70; 1977.

10. Machado MH, Aguiar Filho W, Lacerda WF, Oliveira E, Lemos W, Wermelinger M, et al. Características gerais da enfermagem: o perfil sócio demográfico. Enferm Foco. 2016 [cited 2020 Jan 15];7(esp):9-14. Available from: http://biblioteca. cofen.gov.br/wp-content/uploads/2016/07/Características-gerais-daenfermagem-0-perfil-sócio-demográfico.pdf

11. Santos APA, Camelo SHH, Santos FC, Leal LA, Silva BR. Nurses in post-operative heart surgery: professional competencies and organization strategies. Rev Esc Enferm USP. 2016;50(3):474-81. doi: https://doi.org/10.1590/ S0080-623420160000400014

12. Melo AB, Gomes BRS, Pinheiro BSB, Martins LFJ, Palheta MG, Santos RSU, et al. A gestão de materiais médico-hospitalar em hospital público. Rev Eletrôn Gestão Saúde. 2016 [cited 2020 Jan 15];7(1):369-87. Available from: https:// periodicos.unb.br/index.php/rgs/article/view/3433/3119

13. Calheiros TRSP, Santos AFS, Almeida TG. Atribuição do enfermeiro na gestão da unidade de terapia intensiva. Rev Ciênc Biol Saúde Unit. 2018 [cited 2020 Jan 15];5(1):11-20. Available from: https://periodicos.set.edu.br/index.php/ fitsbiosaude/article/view/5448/3077

\section{- Corresponding author:}

Raísa Gabrielle dos Santos Andrade Email: andraderaisa24@gmail.com
14. Soares MI, Camelo SHH, Resck ZMR, Terra FS. Nurses' managerial knowledge in the hospital setting. Rev Bras Enferm. 2016;69(4):676-83. doi: https://doi. org/10.1590/0034-7167.2016690409i

15. Reis LB, Barbosa IA, Soares LJF, Cruz IM, Souza LPS, Silva CSO, et al. Análise das reprovações de materiais médico-hospitalares de um hospital de ensino. RAHIS Rev Adm Hosp Inov Saúde. 2015;12(3):10-21. doi: https://doi.org/10.21450/ rahis.v12i3.2432

16. Silva JCB, Silva AAOB, Oliveira DAL, Silva CC, Barbosa LMS, Lemos MEP, et al. Profile of the nurse in the management of hospital services. J Nurs UFPE On Line. 2018 [cited 2020 Jan 15];12(10):2883-90. Available from: https://periodicos. ufpe.br/revistas/revistaenfermagem/article/view/236307

17. Silva LF, Afonso T, Sousa CV, Afonso BPD. Vulnerabilidade e riscos de ruptura no abastecimento de materiais e medicamentos na cadeia de suprimento em um hospital público. Rev GEPROS. 2018;13(2):21-43. doi: https://doi. org/10.15675/gepros.v13i2.1832

18. Bugs TV, Rigo DFH, Bohrer CD, Borges F, Oliveira JLC, Tonini NS. Dificuldades do enfermeiro no gerenciamento da unidade de pronto-socorro hospitalar. Rev Enferm UFSM. 2017;7(1):90-9. doi: https://doi.org/10.5902/2179769223374

19. Silva SL. 0 custo do desperdício de materiais para as instituições de saúde [dissertação]. Rio de Janeiro:UniversidadeFederal do Estado do Rio de Janeiro;2016 [cited 2020 Jan 15]. Available from: http://www.repositorio-bc.unirio.br:8080/ xmlui/bitstream/handle/unirio/10957/Disserta\%C3\%A7\%C3\%A30_\%20 Sarah\%20Lopes\%20Silva-1.pdf?sequence=1

20. Santos DM, Souza NVDO, Franco VQ, Silva PAS, Gonçalves FGA, Pires AS. Os trabalhadores de enfermagem e a prática de adaptar e improvisar no ambiente hospitalar. Rev Enferm Atual. 2019 [cited 2020 Jan 15]; 85(23). Available from: https://revistaenfermagematual.com/index.php/revista/article/view/245

\section{Associate editor:}

Dagmar Elaine Kaiser

Received: 03.27.2020

Approved: 08.04.2020
Editor-in-chief:

Maria da Graça Oliveira Crossetti 